\title{
Thinking of Kalam Ulama Aceh XX Century Shaykh Mudawali Al-Khalidi (1917-1961)
}

\author{
Teuku Wildan', Sukiman ${ }^{2}$, Amroeni Drajat ${ }^{2}$ \\ ${ }^{1}$ Ph.D Student in State Islamic University of Sumatera Utara (UINSU), Medan, Indonesia \\ ${ }^{2}$ Lecturer in State Islamic University of Sumatera Utara (UINSU), Medan, Indonesia \\ wildanlgs@gmail.com
}

\begin{abstract}
This paper tries to review and analyze the thoughts of the twentieth-century Acehnese ulama, Shaykh Mudawali Al-Khalidi, who was one of the charismatic ulama of Aceh in the twentieth century, because in the context of Aceh, the role of a dayah ulama was very influential in people's lives. The problem of kalam thinking that often becomes a hot conversation at any time for example about the acts of servants, the will or justice of God and eschatology, which is believed to be able to answer the problems of the Ummah and there will be a basic concept about it, where the Acehnese people who are known to be harmonious and polite bring many basic foundations kalam that makes them live peacefully. Abuya Mudawali in giving his views on the acts of the servants of God and God gave optional for the servants so that later there would be justice for the servants of God in life after death (eschatology) these three problems are interrelated with each other, then there must be consistency of thought.
\end{abstract}

Keywords: Al Quran; Sufism; eschatology; thought.

\section{Introduction}

For Muslims in Indonesia, especially in Aceh, dayah scholars play an important role. Not only in religious matters, but also includes other fields, such as social, political and cultural. Even Clifford Geertz himself called the scholars as cultural brokers (cultural brokers). ${ }^{1}$ Unfortunately, the importance of this cleric has not been matched by studies that have tried to dissect the historically important role of Islamic thought in the dayah scholars in Aceh. This is where the significance of the presence of this research is. This research is intended to see the development of ulama's thinking in the face of globalization which is possible to be affected by the development of the times which requires them to adjust to the circumstances of the times so that their thought shifts in their kalam.

Therefore, the thoughts and enlightenment that had been initiated and practiced by Aceh's ulama, as explained above, need to be reexamined into very careful research and writing, so that they can be used as important documentation for Aceh in the field of ulama thought. Of course documentation, research and writing of books on Acehnese ulama's thinking have been carried out, both by academics and by other researchers. But the documentation is still very limited and only revolves around known scholars such as Hamzah Fansuri, Syamsuddin As-Sumatrani, Nuruddin Ar-Raniri or Abdurrauf As-Singkili, or several other scholars. Even though there are still many Acehnese scholars who have played a role and made a big contribution in Aceh especially in the XX century, which needs to be examined or reviewed. In the opinion of researchers, so far there has never been done a study and writing of books on the thoughts of the Aceh Islamic dayah ulama in various aspects.

\footnotetext{
${ }^{1}$ Clifford Geertz, The Religion of Java(Chicago and London: The University of Chicago Press, 1960), and Clifford Geertz, "The Javanese Kijaji: the Changing Role of a Cultural Broker," in Comparative Studies in Society and History, Vol. 2 No.2 (1960), p.228-249
} 
When talking about the problem of Acehnese ulama's thinking, it cannot be separated from the name of dayah or boarding school, it helps us to look at the education system taught at dayah (Boarding school) not much different from the material presented by Meunasah (surau) but the material taught is the book of Nahu, which means the book in Arabic, even though the meaning of Nahu itself is grammar (Arabic). Dayahs are usually near mosques, although there are also nearby Teungku who have the dayah itself, especially those with high levels of study. Therefore people who want to learn cannot learn part-time, for that they must choose a dayah that is a little far from their village and stay in the dayah called Meudagang. In the dayah there were provided small huts to load two people per house. In the book written by Hasbullah, History of Islamic Education in Indonesia, the term Rangkang is a madrasah as short as Tsanawiyah, the material taught is Arabic, earth science, history, counting, and morals. The Rangkang is also held in every resident. ${ }^{2}$

\section{The Thoughts of Shaykh Mudawali Al-Khalidi}

Abuya Muhammad Wali Al-Khalidi is a cleric born from a religious family. He got an education from a small boarding school / dayah. The santri and the community addressed him as Abuya Mudawali (hereinafter abbreviated as Abuya Mudawali). He was one of Aceh's charismatic scholars, who lived in the modern era, if examined by his opinions, it could be assumed that he was between two traditional and rational poles, He acknowledged that between monotheism, Sufism and fiqh are interconnected, these elements must complement each other so that they only make perfection.

Many renewed thoughts from him, from one side he is a traditionalist who adheres to the understanding of Ash'ariyah. As can be noted in his opinions, as in the matter of human actions, Abuya Mudawali argues that all human will, the God who regulates and about the relationship of syara 'and reason, he is more moderate (tawasuth) and balanced (tawazun), not extreme left like Mu'tazilah and extreme right like Hasyawiyah. According to him all religious obligations can only be known through shara 'information (revelation). Spread related to beliefs can only be achieved by reasoning. This is in line with the expression of a Muslim cleric from the Ash'ariyyah school of Al-Imam Abu Ishaq Al-Shirazi in his book AlIsyrah ila Madzhab Ahl Al-Haqq. Abuya Mudawali supports his opinion of God, that is, he believes that Allah is obligatory to be twenty, he also strongly rejects the division of monotheism into three.

Seen from another side the figure of Abuya Mudawali is also a modernist rationalist seen from the changes he made as in the field of education, Abuya Mudawalid in several occasions often popularized the very popular rules among the Nahdlatul ulama, namely Maintaining the previous values is good, and takes on new values that are better. On the basis of these rules Abuya Mudawali has made many updates on all sides.

\section{Productive Changes from Shaykh Mudawali Al-Khalidi}

Abuya Mudawali is very productive in terms of the many changes he has made both in terms of education, socio-culture and even more in terms of his kalam thoughts. If you notice that Abuya Mudawalis a very traditionalist modernist because he is able to balance between

\footnotetext{
${ }^{2}$ Hasbullah, Sejarah Pendidikan Islam di Indonesia, p. 32
} 
the material world life and the spiritual afterlife. Harun Nasution said that with regard to productivity, religion has two teachings that are closely related to productivity. First, religion teaches that after the first life in this material world, there is a second life later in the afterlife which is spiritual. How the influence of this teaching on the productivity of adherents of the religion in question is very dependent on the two features. If world life is considered important, productivity will increase. But, on the contrary, if life in the afterlife takes precedence, productivity will decrease. Second, religion has teachings about human destiny and deeds. If the fate of humans has been determined by God from the beginning, in the sense that human actions are God's creations, then the productivity of people, who embrace such religious understanding, will be very low. However, in society, which embraces the understanding that it is humans who determine their destinies and human beings who create their actions, productivity will be high.

Abuya Mudawali's seriousness in strengthening monotheism and giving appreciation to kalam, was proven by successfully generating at least three of his writings mentioned above, these three works of Abuya Mudawali can be considered as a blueprint of Abuya Mudawali's thought in the field of kalam. Therefore it is a separate reason for this field to be the focus as well as primary data in this study.

From the three writings of Abuya Mudawali, it can reveal the style of kalam thought and provide criticism of kalam thinking that developed in Aceh in the XX century, the assumption of the author that there is a type of kalam thinking that is ideal for the people of Aceh.

To find out how Abuya Mudawali's thoughts are and why he often criticizes the thoughts of the kalam that are developing now in Aceh which are not in accordance with the ulama's understanding, namely the understanding of blind salik. so that a paper was written to reject that thought. it is deemed necessary to have in-depth research and studies to determine the specificity of the thoughts of Abuya Mudawali.

There are two visions in looking at an Abuya Mudawali, he is a character of Aceh's charismatic ulama who is a reference for other scholars especially at this time and one of the biggest dayah leaders in Aceh at that time. On the one hand he is seen as a figure of reformist Islam in Aceh who has a great passion in delivering his nation from the style of static-passive life into a dynamic-revolutionary nation. Through this great desire he is seen as a modernist. While on the other hand, he is claimed to be a tradionalist who while his followers are said to be Ahl Sunnah wal Jama'ah, loyal followers of the Ash'ariyah theology. Abuya Mudawal followed the understanding of Ahl Sunnah wal Jama'ah which was pioneered by Abu Hasan al-Ash'ari (260-324 H / 873-935 AD) and Abu Mansur al-Maturidi (d. 333 H./944 AD). in the field of fiqh, Abuya Mudawal follows the school of Imam Muhammad Ibn Idris ash-Shafi'i (150-XXI4 H./767-8XXI M.). whereas in the field of Sufism, Abuya Mudawal following alJunaid al-Baghdadi (d. 297 H.) and Abu Hamid al-Ghazali (450-505 H./1058-1111 AD) Abuya Mudawali's tendency towards the above schools made Abuya Mudawalidi categorize as a tradionalist person. Abuya Mudawalidimata of the Aceh people is a symbol of renewal in the field of thought.

\section{Af'al Al-Ibad (Human Action) in the view of Shaykh Mudawali Al-Khalidi}

The author would like to study and analyze the opinion of the XXI century Acehnese ulama about the acts of the servant in this case which became the object of his study by an 
Aceh charismatic scholar who was the teacher of the XXI century Acehnese scholar, Shaykh Mudawali Al-Khalidi (1917-1961).

In the case of human actions and the power used in carrying out the work of theologians, they are divided into two broad groups. Rational-wing groups hold that servant's actions are the result of human's own will and activities with the power given by God before the actions occur. On the other hand, for theologians who have traditional beliefs that human actions are acts of God done by humans, but there is a human effort in them termed kasb.

It has been agreed by the scholars that Allah has created servants and all acts of servants who are idhtirariyyah, they differ in opinions about actions which are endeavor able (effort) to the servant, the group that considers the Asy'ariyah to agree that the actions of the servants who are idhrirariyah and ikhtiariyah are God's creations. If I do well and bad, it is also God's creation, so as a man, we who believe have nothing to do except with good deeds to God. Then the bad deeds are connected with ourselves by what has been attempted (kasb) by the servant and connected to Allah with the way Allah created the deeds.

Human will, power and actions are closely related to the issue of destiny, as explained by one of the members of the Naqsyabadiyah Congregation of the Islamic Boarding School of the Samalanga Grand Mosque, Teungku Muttaqien Muhammad Yunus, according to him there are 4 groupings of Divine Destiny, including:

1. Destiny in God's knowledge. This can't change anymore.

2. The destiny written on luh mahfuzh. This can change, if God wills.

3. Fate in the mother's womb. This is in accordance with Luhul Mahfudz.

4. Divine destiny in reality, which is made into something in reality according to predetermined destiny

He asserted to researchers, that Muslims believe in Divine destiny, but humans are commanded by God to work diligently and try as hard as possible, then anything will be facilitated by God for us then that is a sign for destiny that has been set for us. ${ }^{3}$

Abuya Mudawali, gave an overview of the problem of destiny, this destiny has two parts. Destruction of destiny and destiny of mu'allaq, then that is called destiny of mughram is destiny that cannot be changed anymore as written in azali, and destiny of mu'allaq is a fate that is attributed to something, like a person will become smart with the record of having to go to school. ${ }^{4}$ As revealed by a great Asy'ariyah scholar, Ahmad Syihabuddin Ibn Hajar alHaitami in his essay, Kitab al-Fatawa al-Hadistah. ${ }^{5}$

There is a comparison that can be analogous, as when a Muslim is sick, then goes to see a doctor and drink it, then he must ask God to make something to give him health because it is only God who creates health. Human will is not entirely from the human itself but there is a contribution from God as well. This is called giving endeavor to humans that God has given. Human actions are divided into two categories, idhirariyyah and ikhtiyariyah, what is meant by idhirariyyah is the will of something that is naturally a basic human need such as shivering from fever or trembling because of fear, the irti'ash (reflex movement) action is solely a matter of nature. from God, because there is no deliberate servant in doing, put up the will of ikhtiariyyah is a will that is chosen and decided consciously by humans because it is

\footnotetext{
${ }^{3}$ Mudawali, Tanwir Anwar. p. 16

${ }^{4}$ Mudawali, Tanwir Anwar. p. 18

${ }^{5}$ Ahmad Syihabuddin Ibn Hajar al-Haitami, Kitab al-Fatawa al-Hadistah, (Beirut: Dar al-Fikr, tt), p. 92.
} 
considered to contain the value of religious observance. ${ }^{6}$ Or Ikhtiyariyah is something that is seen as human actions because there is qudrah in it which is called kasb by Asy'ariyah prostitution that comes out of servants whose nature is choice (choice) nationalized to the servant called iktisab meaning effort. Therefore, the first type of will has a lower value than the second type of will.

The freedom that God gave to Adam and Eve during heaven to enjoy whatever is in heaven according to their will, but the freedom to do what God gave Adam and Eve is not without rules, in heaven there are trees that can be approached and the fruit is eaten and there is a tree that is prohibited from being approached, if approached it means a tyranny, humanly Adam and Eve are able to approach the trees because God has given endeavor (effort) to both of them. So the freedom that God gives is regular freedom in the sense that both are free to choose and do whatever they want for their survival, as long as they do not violate certain rules set by God.

A servant does not create his actions and nor is the servant forced to do it, God has created the actions that arise from that servant and the condition of the servant has an act that God marries which is called ikhtiyariyyah (effort). ${ }^{7}$ The servant does not have absolute power over his actions and is not absolutely forced, but in the middle between power and force.

A servant does not create his actions and nor is the servant forced to do it, God has created the actions that arise from that servant and the condition of the servant has an act that God marries which is called ikhtiyariyyah (effort). The servant does not have absolute power over his actions and is not absolutely forced, but in the middle between power and force.

Abuya Mudawali views that human deeds are the will and actions of God but there are human efforts in them that play a role so as to produce actions that are nationalized to human actions. However, not all actions that result from human activities are a combination of God's qudrat with human sacred. But those belonging to this problem are only actions that endeavor only. The holy and noble qudrat of God united with the qudrat of the servant produces works that are sincere. But the effective qudrat is only God's qudrat while the servant's qudrat is ineffective. Abuya Mudawali compared the servant's actions like a giant who was lifting a large stone and then a small child put his small and weak hand on the stone. Therefore it cannot be said that the child did not participate in the activity, except that his role was not effective. Regarding human actions, Sheikh Ibrahim al-Fatani recited in a vowel which means: On our side for me there is a business that is charged. Know (but) the business does not give a mark.

Acts of servants according to Abuya Mudawali are clearly God's actions. Everything the servant does is none other than God's work, but there is human effort in it. Human effort in terms of choosing its efforts to do obedience or immorality, because the choice of this business is human, the human endeavor is endeavor.

Acts made by the servant on the basis of human consciousness itself, because humans have been given the initiative (effort) by God. Teungku Teuku Muhammad Rifqi argues about kasb, where humans are able to use the power they have if the power in humans is supported by God. As humans lift large stones, in essence according to him it was God who raised the large stones, but that does not mean humans did not lift. In this case, that human is

\footnotetext{
${ }^{6}$ Ibrahim Ibn Muhammad Al-Bayjuri, Tuhfah al-Murid, (Surabaya: Al-Hidayah), p. 62

${ }^{7}$ Mudawali, Tanwir Anwar p. 27
} 
indeed given power by God but the use of that power must be in accordance with God's will. ${ }^{8}$ What he said was like the view of the Asy'ariyah scholar Mawlana Diya 'Addin. ${ }^{9}$

What the servant does during his life there will be accountability in the hereafter, he said what was done by the servant will be held accountable later in the hereafter, as there is in Surah al-Baqarah verse 286, the meaning: "For man (reward) what he is trying to do and for man (punishment) what he is trying to do"

Humans will be rewarded for what they have done or worked out well and will be punished if he tries and does new things. ${ }^{10}$

With regard to human responsibility for the good and bad deeds of the majority of the congregation, their argument is that human actions are endeavored to come from two different qudrat namely the Lord's qudrat with the version of making and qudrat the servant with the business version. I have not done anything nor made it. It's just that choosing on his efforts is to make or leave it so that it becomes an act that is nationalized to me. Because he chose this choose he was rewarded, for the choice to obey and given sin for the choice to commit immorality. Therefore, there will be confusion and reason, if the servant's actions are God's actions there will be difficulties in the accountability of these actions. It is unfair if God tortures the servant who did bad even though it was not he who did it but God himself.

Responding to this problem, Abuya Mudawali strongly rejects the opinion of the rational Mu'tazilah who holds that human actions occur in accordance with human will. If someone wants to do something that does not happen. But on the contrary if a person does not want to do something that does not happen. If human deeds are not human deeds but deeds of God, then their actions will not occur even if he desires and desires those actions, or his actions will occur even if he does not want and does not want them. With this argument there will be no difficulty in terms of the responsibility of the servant because the action is the will and the activities of the servant are asked to be held accountable. Worth getting merit if doing good and deserved also if doing immoral.

In the matter of justice, Abuya Mudawali views that, Allah is in power and will in absolute terms. Thus, events, processes of performance of the universe (cosmos) and so on are under the control of His absolute power and will. Humans, who because they form a small part of the universe, also cannot escape His control. With that conviction, Asy'ariyyah interpreted qadha as a form of Allah's provision which is part of His inspiration to all beings. And qadar as a manifestation (manifestation) of these provisions that will not change. Because basically, life on earth is the realization of God's record in the days of azali, whether it involves good or bad events, profit or loss, happiness or bitterness, and so forth from the time humans are born until they die.

The obligation to believe in qadha and qadar, as the view of Abuya believes in all human actions based on the will (iradat) of God since the time of azali, whether done by the will of man himself (ikhtiariyah) or natural (idhthirariyah). The author of al-Jawahir alKalamiyyah's book, Tahir Ibn Shalih Al-Jazairi also stated the same thing. ${ }^{11}$

\footnotetext{
${ }^{8}$ Mudawali, Tanwir Anwar. p. 21

${ }^{9}$ Mawlana Diya' Addin dan Khalid al-Baghdadi, Belief and Islam (Istanbul-Turkey: Hakikat Kitabevi, 1986), p. 64.

${ }^{10}$ Mudawali, Tanwir Anwar. p. 20

${ }^{11}$ Tahir Ibn Shalih al-Jazairi, al-Jawahir al-Kalamiyyah (Surabaya: Al-Miftahtt), p. 46.
} 
To prove that all natural events are based on destiny, let's look at a mild analysis of the discipline of physics. Take a peanut, long bean, or potato seeds that have begun to sprout, put it in a pot that has been given wet soil. Make a room with two bulkheads in a box. The first partition gives a little space below, while the second bulkhead is a hole above, so it forms a zigzag path. Then give a small hole on the left side of the cardboard as a place for the entry of light. Put the pot containing the buds on the right side, and then let it sit for how many days. And observe when the shoots have elongated. He will come out of the hole, while the shape of the bud will look curved. Why is that? The answer is of course, because every living thing in this case plants must undergo the path of their destiny, looking for the light that is the source of their life. The shoots which are now in the form of plants, they grow by following the direction of the light where the light enters. This is the undeniable law of nature. Engineered like any seed shoots earlier, then he will still look for a light source.

Qadha is Allah's provision for all creation. While qadar is an embodiment of these provisions, which will not decrease and increase at all. Shoots that grow zigzagging to find the source of light, continue to run above the provisions of qadha and qadar. Based on the provisions of this god, basically human life on earth is a realization of the lines of the provisions of God in the days of azali. Whether it concerns good or bad luck.

\section{Conclusion}

From the results of the above research in concluding that the thought of kalam abuya mudawali is still very much influenced by the thought of kalam sunni or asy'ariyyah, this is clearly seen in his views on the problem of kalam thought, where abuya mudawali argues about the actions of the servant not created by the servant but by God and God gave to the servant namely ikhtiariyyah (al-kasb / effort) to do the deed and Allah also gave to the servant idhtirariyyah (natural). The view of Abuya Mudawali justice to God is absolute, God is not obliged to do good to the servant as well as about Qadha and Qadar, Qadha is the provision of Allah for all His creatures and Qadar is a manifestation of Allah's provisions for His creatures.

Regarding eschatology, abuya mudawali argues that life after death is a sure thing, servants who do good will place God in heaven and who do bad things about god torture and doom in hell, abuya mudawali believes that the resurrection day in the grave until humans are led to heaven, the existence of mizan (scales) on the practice of my servant, shirad (titi) and the existence of a heaven of hell is a certainty in the concept of eschatology, the servant will be responsible for all his deeds according to his actions during life in the world. I will be resurrected on the hereafter of the body and soul, as is the belief of the Ashariyya School. 


\section{References}

Ahmad, Daudy. (1983) Allah dan Manusia dalam Konsepsi Syeikh Nuruddin ar-Raniry, Jakarta: Rajawali.

Abu Abdillah Al-Bukhari, Shahih Al-Bukhari, (Lebanon: Dar al-Ilm, t.t

Azra, Azyumardi. (2013) Jaringan Ulama Timur Tengah dan Kepulauan Nusantara Abad XVII-XVIII. Jakarta: Kencana Prenada Media Group.

Al-Imam Abu Ishaq Al-Syirazi. (1999) Al-Isyrah ila Madzhab Ahl Al-Haqq. Kairo: Al-Majlis al-A'la lil Syu'un Al-Islamiyyah.

Abdul Karim Usman, (1971) Nahriyah al-Taklif, Arau al-Qhadhy abd al-Jabbar alKalamiyyah, Bairut: Muassasah al-RisalaH.

Ahmad Syihabuddin Ibn Hajar al-Haitami, Kitab al-Fatawa al-Hadistah,Beirut: Dar al-Fikr, tt

Abi Bakr Ibn Thayib al-baqillani. (1993) Al-Inshaf fi ma Yajibu I'tiqaduh wa la Yajuzu alJahlu fih, Tahqiq: Muhammad Zahid bin Hasan Al-Kautsari, cet 3, Kairo: Maktabah Al-Khanaji,

Asy-Syahrastani. (2006) Al-Milal wa Nihal, Pen. Prof, Asywadie Syukur, Al-Milal wa Nihal Aliran-Aliran Teologi Dalam Sejarah Umat Manusia, PT Bina Ilmu, Surabaya.

Atabik Ali dan Ahmad Zuhdi Muhdhar, Kamus Kontemporer Arab-Indonesia, Cet II, Yogyakarta: Yayasan Ali Maksum Pondok Pesantren Krapyak

B.J. Boland. (1982) The struggle of Islam in Modern Indonesia The Hague: Martunis Nijhof.

Clifford Geertz. (1960) The Religion of Java (Chicago and London:TheUniversityof ChicagoPress, 1960, dan Clifford Geertz, "The Javanese Kijaji: theChanging Role of Cultural Broker," dalam Comparative Studiesin Societyand History, Vol.2No.2

Ensiklopedi Islam. (1999) vol. V, Jakarta: PT. Ichtiar Baru Van Hoeve.

Fazlur Rahman, (2000) Islam, terj. Ahsin Muhammad, Bandung: Penerbit Pustaka.

Howard M. Farderspiel. (1970) Persatuan Islam: Islamic Reform In Twentieth Century Indonesia Ithaca, New York: Medern Indonesia Project, Cornell University.

Harry J. Benda. (1958) The Crescent and The Rising Sun: Indonesian Islam Under The Japanese Occupation 1942-1945 The Hague and Bandung: W. Van Hoeve.

Himpunan Fatwa Majelis Ulama Indonesia Jakarta: Depertemen Agama, 2003

Harun Nasution. (1998) Islam Rasional: Gagasan dan Pemikiran, Bandung: Mizan.

Ismail Ya'kob (2001) “Dayah Manyang” dalam muliadi kurdi (ed), Kajian Tinggi Keislaman (Banda Aceh: Biro Keistimewaan dAn Kesejahtraan, Prov. NAD.

Ibrahim Ibn Muhammad Al-Bayjuri, Tuhfah al-Murid, Surabaya: Al-Hidayah

Ibn Sina. (1960) al-Isyârât wa at-Tanbihât, Kairo: Dâr al-Fikr.

Imam al-Haramain al-Juwaini. ( 1995) Kitab al-Irsyad Ila Qawa'id al-Adillah fi Ushul alI'tiqad, cet I, (Beirut: Dar al-Al-Kutub Al-Ilmiyah,.

Ilhamuddin. (1997) pemikiran kalam al-Baqillani studi tentang persamaan dan perbedaannya dengan al-Asy'ari, cet 1, Yogyakarta: Tiara Wacana Yogya.

Lorens Bagus (1996) Kamus Filsafat, Jakarta: Gramedia.

Muhammad Wali Al-Khalidi, Tanwirul Anwar, Banda Aceh: Maktabah At-Taufiqiyah AsSa'adah.

Martin van Bruinessen. (1995) Kitab Kuning, Pesantren dan Tarekat; Tradisi Islam di Indonesia, Bandung: Mizan.

M. Ibrahim, et.al, Sejarah Daerah Propinsi Daerah Istimewa Aceh 
Muhammad Said, Aceh Sepanjang Abad, Cet.IV, Medan: Harian Waspada, tt

Mawlana Diya' Addin dan Khalid al-Baghdadi. (1986) Belief and Islam Istanbul-Turkey: Hakikat Kitabevi.

Mircae Eliade (ed). (1987) "Eschatology", The Encyclopedia of Religion, (New York: Macmillan Publishing Company.

Paul Edward (ed.), "Eschatology". Encyclopedia of Philosophy, (New York : Macmillan Publishing

Peter A. Angeles, (1981) Dictionary of Philosophy, New York: Harper \& Row Publishers.

Sangidu, Wachdatul Wujud, Yogyakarta: Gama Media

Sudardi, Budi. (2003) Sastra Sufistik: Internalisasi Ajaran-ajaran Sufi dalam Sastra Indonesia, Solo Tiga Serangkai Pustaka Mandiri.

Syekh Naquib (1996) Al- Attas, Raniri and the Wujudiyyah of 17th, Century Aceh, Singapore, MMBRAS III.

Sirajuddin Abbas (1972) Sejarah dan Keagungan Mazhab Syafi'i, Cet.II, Jakarta: Pustaka Tarbiyah.

Syaikh Haji Muhammad Wali Al-Khalidi, Tanwir Al-Anwar, (Banda Aceh, Maktabah atTaufiqiyyah As-Sa'adah, tt

Tahir Ibn Shalih al-Jazairi, al-Jawahir al-Kalamiyyah Surabaya: Al-Miftahtt

Weekes V. Richard, (1984) Introduction, Muslim People, A World Ethographic Survey, London: Aldwych Press. 